\title{
NIPA1 Gene
}

National Cancer Institute

\section{Source}

National Cancer Institute. NIPA1 Gene. NCI Thesaurus. Code C75736.

This gene may be involved in the development of the nervous system. 